\title{
Article
}

http://dx.doi.org/10.11646/phytotaxa.245.2.7

\section{Mormodes salazarii (Orchidaceae, Catasetinae), a new species with greenish-white flowers from Costa Rica}

\author{
MARIO A. BLANCO ${ }^{1,2}$, JOSÉ ESTEBAN JIMÉNEZ ${ }^{3}$ \& PEDRO JUÁREZ ${ }^{4}$ \\ ${ }^{1}$ Jardín Botánico Lankester, Universidad de Costa Rica, Apdo. 1031-7050, Cartago, Costa Rica; e-mail: mario.blancocoto@ucr.ac.cr \\ ${ }^{2}$ Escuela de Biología, Universidad de Costa Rica, Ciudad Universitaria Rodrigo Facio, Apdo. 11501-2060, San José, Costa Rica. \\ ${ }^{3}$ Programa Regional de Posgrado en Biología, Universidad de Costa Rica, Apdo. 11501-2060, San José, Costa Rica. \\ ${ }^{4}$ Escuela de Ciencias Ambientales, Universidad Nacional de Costa Rica, Apdo. 86-3000, Heredia, Costa Rica.
}

\begin{abstract}
Mormodes salazarii (Orchidaceae, Catasetinae), a new species apparently endemic to Costa Rica, is described and illustrated. It is similar to $M$. fractiflexa because of its non-resupinate flowers, entire lip and revolute margins of sepals and petals, but differs from that species by its erect flowers (vs. pendulous) and strongly reflexed lateral sepals without colored lines (vs. widely open or slightly reflexed lateral sepals with red blurred lines).
\end{abstract}

\section{Resumen}

Se describe e ilustra Mormodes salazarii (Orchidaceae, Catasetinae), una nueva especie aparentemente endémica de Costa Rica. Es similar a $M$. fractiflexa por sus flores no resupinadas, labelo entero y los márgenes revolutos de sépalos y pétalos, pero difiere de esa especie por sus flores erectas (vs. péndulas) y sépalos laterales fuertemente reflexos y sin líneas de color (vs. sépalos laterales ampliamente extendidos o ligeramente reflexos, con líneas rojas borrosas).

Key words: Seasonal forest, Reserva Biológica San Luis, Monteverde

\section{Introduction}

Mormodes Lindley (1836: 446) is a genus comprising ca. 80 species (Salazar 1994b, 1999; Salazar et al. 2009), distributed from Durango and Querétaro in Mexico to Bolivia and southeastern Brazil (Salazar 1999). It is a member of the subtribe Catasetinae Lindley (1843a: sub t. 22, as "Catasetidae"), a group of exclusively Neotropical orchids that, in its traditional circumscription, also includes Catasetum Rich. ex Kunth (1822: 330), Clowesia Lindley (1843b: 25), Cycnoches Lindley (1833: 154) and Dressleria Dodson (1975: 131) (Dressler 1981, Romero 1990, Pridgeon \& Chase 1998, Romero \& Pridgeon 2009). Some recently proposed classifications (e.g., Chase et al. 2015) also include the genera Cyanaeorchis Barbosa Rodrigues (1877: 112), Galeandra Lindley (1830: sub pl. 8) and/or Grobya Lindley (1835) in an expanded Catasetinae. Other classification proposals (e.g., Chase et al. 2003) include Cyrtopodium Brown (1813: 216) in this subtribe, but recent molecular evidence strongly suggests that Cyrtopodium does not belong to this clade (Batista et al. 2014, Whitten et al. 2014, Chase et al. 2015, Freudenstein \& Chase 2015).

Species of Mormodes are saprolignophilous epiphytes (i.e., usually growing on dead, decomposing wood), with asymmetric flowers and a column that is twisted and touches the labellum surface at anthesis, but straightens and separates from the labellum a few hours after removal of the pollinarium (Dressler 1993, Salazar 1994b, 1999). The relatively large flowers are visited and pollinated by male euglossine bees, which collect fragrances from the surface of the labellum (Dodson 1962, van der Pijl \& Dodson 1966, Dressler 1968). The stipe of the pollinarium sits curved under tension and is forcefully triggered outward when the pollinator contacts the apical filament of the column. Some species show floral dimorphism (with functionally pistillate and staminate flowers, produced on either the same or separate inflorescences) or polymorphism (with flowers of any intermediate degree of sexual expression); other species have uniformly monomorphic, protandrous flowers (Dodson 1962, Dressler 1968, Salazar 1994b). 
Currently, the genus has two sections recognized. Species of section Mormodes produce inflorescences from nodes near the middle of the pseudobulbs when these are mature and leafless (typically during the dry season). Species of section Coryodes Pfitzer (1888-1889: 159) produce inflorescences from nodes near the base of the pseudobulbs, while these are actively growing and still have their leaves during the rainy season (Salazar 1994b, Salazar et al. 2009).

The circumscription of the genus has remained unchanged since 1836 when it was established and, with the exception of an unpublished systematic study of Mormodes sect. Coryodes (Salazar 1999), it has never been revised (Salazar 1994b). Most studies of this genus to date have been focused on describing new species, regional synopses (Pabst 1968, Dressler 1993, Salazar 1994a, Salazar \& Romero 1994, Salazar \& Dressler 2003) and regional keys (Pabst 1978, 1982). Morphological (Romero 1990) and molecular phylogenetic analyses (Chase \& Hills 1992, Pridgeon \& Chase 1998, Pérez-Escobar et al. 2016) suggest that Mormodes is monophyletic and sister to Cycnoches.

The species-level taxonomy of Mormodes is problematic because of the relative scarcity of material available in herbaria, the significant variation in size and color of the flowers (Allen 1959, Dodson 1962, Horich 1976, Pabst 1978), and the frequent production of dimorphic or polymorphic flowers (Dodson 1962, Dressler 1968, Salazar 1991, 1994b, Monnier 1992, Salazar et al. 1999). In addition, many features of the fleshy flowers are distorted or obscured upon press-and-dry herborization; thus, characterization of these plants is best done using live or spirit-preserved material. The new species proposed here has been known from a handful of herbarium specimens, and live material was found only recently as a result of a floristic inventory carried out in the San Luis Biological Reserve, in the Monteverde region of northwestern Costa Rica (Jiménez et al., in press).

Mormodes salazarii M.A. Blanco, J.E. Jiménez \& P. Juárez, sp. nov. (Figs. 1, 2)

Similar to Mormodes fractiflexa Reichenbach (1872: 141) because of its non-resupinate flowers, entire lip and revolute sepals and petals, but differs from that species by its erect flowers (vs. pendulous) and strongly reflexed lateral sepals without colored lines (vs. widely open or slightly reflexed lateral sepals with red blurred lines).

Type:-COSTA RICA. Prov. Puntarenas: cantón Puntarenas, distrito Monteverde, Reserva Biológica San Luis, 664 m, 10¹5’43” N, 8449’41” W (WGS84), collected without flowers by J.E. Jiménez \& P. Juárez on November 2013, flowered in cultivation in San José, Costa Rica on 24 February 2014, M. Blanco 4749 (holotype: USJ!).

Plants sympodial, caespitose epiphytes. Pseudobulbs long-ovoid to ellipsoid, partially covered by the leaf sheaths, $5.0-8.5 \times 1.8-3.0 \times 1.5-2.8 \mathrm{~cm}$ (in life), bearing 9-11 evenly spaced leaves. Leaves amplexicaul, sheaths with free margins (not forming a closed tube), mostly adpressed to pseudobulb, whitish, dry and scarious during anthesis; abscission line transverse, with 3 short (1-2 mm long) spiny vein remnants; blades absent during anthesis, not seen. Inflorescence 1 per pseudobulb, emerging from a node in the lower third of the mature pseudobulb, ascending, with 2-5 flowers, up to $21 \mathrm{~cm}$ long; rachis more or less straight, up to $15.5 \mathrm{~cm}$ long, $7 \mathrm{~mm}$ in diameter at the base, $3 \mathrm{~mm}$ in diameter at the point of insertion of the most distal flower, pale green, with up to 7 internodes before the first flower (these shorter toward the base), internodes between flowers 1.0-3.5 cm long; bracts whitish, dry and scarious during anthesis; the basal, flowerless ones amplexicaul, subtriangular, adpressed to the rachis, up to $7 \mathrm{~mm}$ long; the ones bearing flowers not amplexicaul, ovate, 5-6 × 3-4 mm. Flowers non resupinate, sepals and petals greenish white (turning pale yellow when older), column and labellum white to yellowish, without noticeable fragrance, apparently monomorphic. Pedicel and ovary cylindrical, $2.7-3.2 \mathrm{~cm}$ long, $2 \mathrm{~mm}$ in diameter basally, $3 \mathrm{~mm}$ in diameter apically. Lateral sepals narrowly elliptic to lanceolate, slightly asymmetric, basally truncate, acute, margins revolute, 26-31 $\times$ 7-9 $\mathrm{mm}$ when flattened (appearing $6 \mathrm{~mm}$ wide when not flattened because of the revolute margins), strongly reflexed and embracing the pedicel and ovary, straight. Dorsal sepal narrowly elliptic, basally truncate, acute, margins revolute, 30-31 $\times 7-8 \mathrm{~mm}$ when flat (appearing $4 \mathrm{~mm}$ wide because of the revolute margins), reflexed, straight. Petals elliptic, basally truncate, acute, margins revolute, $27-31 \times 10-11 \mathrm{~mm}$ when flattened (appearing $6 \mathrm{~mm}$ wide when not flattened because of the revolute margins), erect, slightly arched forward. Labellum transversely elliptic, basally long-unguiculate, apiculate, limb convex, saddle-like, incurved, with the sides strongly bent down, 22-26 × 19-22 mm when flat (limb appearing $8 \mathrm{~mm}$ wide and $10 \mathrm{~mm}$ deep because of the revolute sides), slightly asymmetric (rotated to one side); claw 5-6 $\times 2-3 \mathrm{~mm}$. Column semiterete, arched and twisted ca. 90 degrees throughout its length, the apical filament linear, $3 \mathrm{~mm}$ long, firmly adpressed against the center of the labellum limb; 16-19 $4 \mathrm{~mm}$. Anther incumbent, ovate and long-acuminate, ejecting the pollinarium upon contact. Pollinarium 5-6 $\times 1.7-2 \mathrm{~mm}$, with a white viscidium and stipe; pollinia 2 yellow; viscidium and stipe oxidizing dark brown ca. 10 minutes after ejection from the column; viscidium oval, cushion-like, $2.5 \times 1.8 \times 1.2 \mathrm{~mm}$; stipe oblong, $4-5 \times 1.5-2 \mathrm{~mm}, 2.5$ wide at insertion of pollinia, with a rounded denticle $1 \mathrm{~mm}$ long between the bases of pollinia, strongly arched immediately after ejection but partially 
straightening out when dry; pollinia ovoid, inserted subapically on the ventral surface of stipe, $1.8 \times 1 \mathrm{~mm}$. Stigma a pale green, shiny, sticky cavity on the ventral surface of the column, almost as wide as the column, 7-8 $\times 4 \mathrm{~mm}$, basally rounded, apically truncate. Fruit a dehiscent, ellipsoid, capsule, smooth, with three low $(1 \mathrm{~mm})$, rounded, longitudinal keels aligned with the sepals, pale green when immature, $5.5 \times 2.3 \times 2.4 \mathrm{~cm}$ before dehiscence, opening by 6 longitudinal slits that separate 3 wide and 3 narrow, alternating valves.
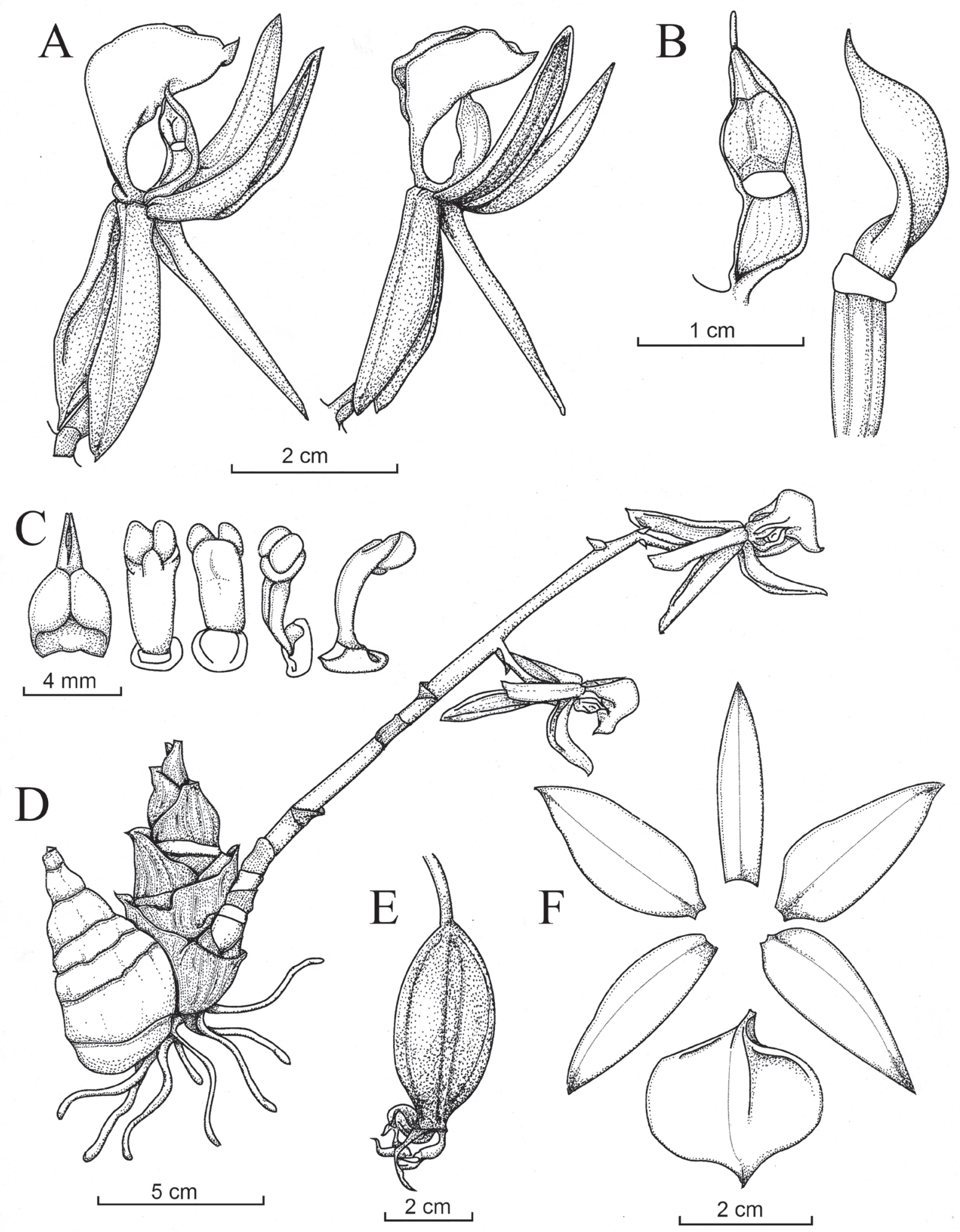

FIGURE 1. Mormodes salazarii. A. Lateral view of two flowers from opposite sides of the inflorescence to show floral asymmetry. B. Columns from the two flowers in A. C. Anther cap (ventral view) and pollinarium (four different views). D. Habit of flowering plant while leafless. E. Undehisced fruit. F. Dissected perianth. Drawn by P. Juárez; A-D and F based on Blanco 4749 (USJ), E based on Jiménez et al. 2263 (USJ). 


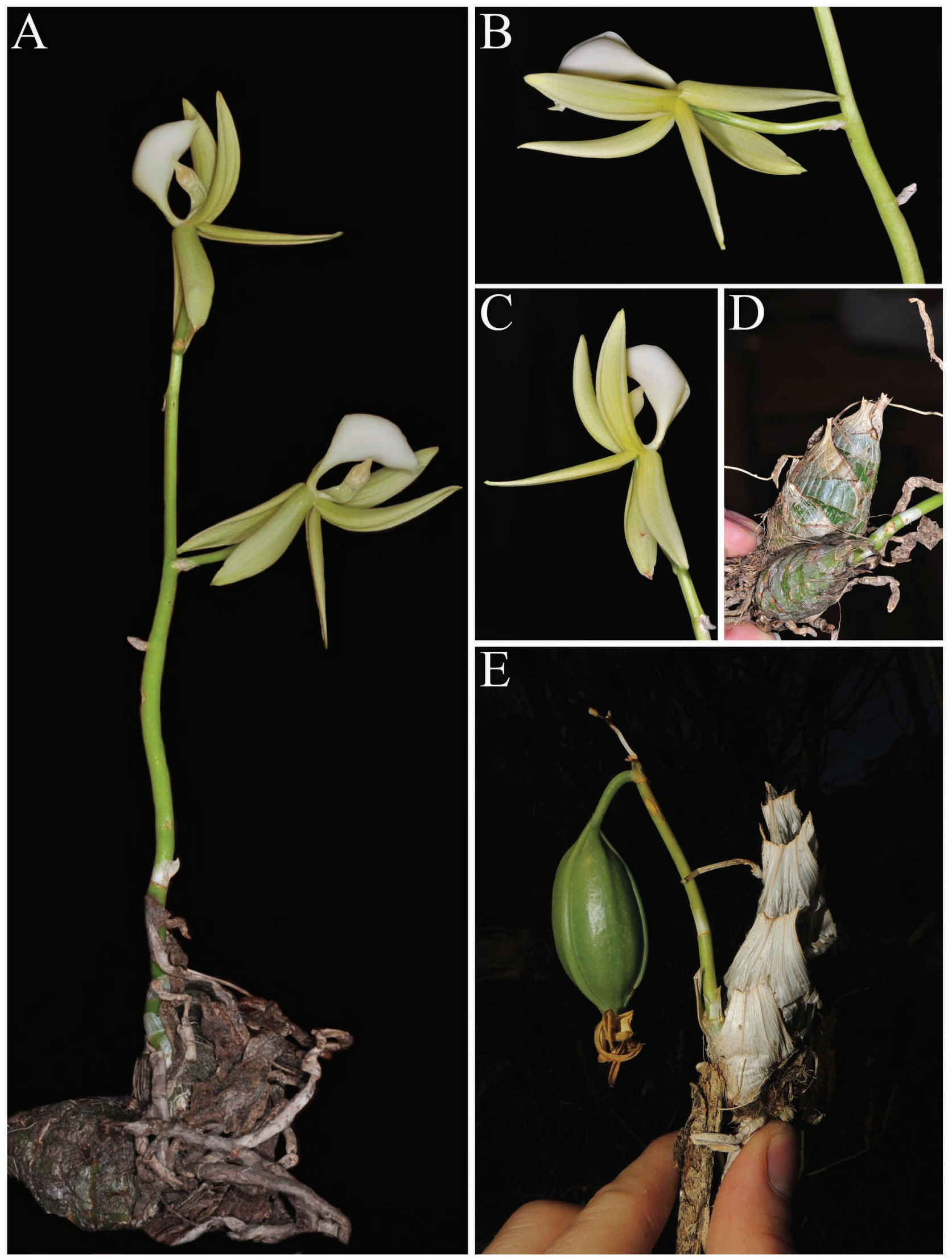

FIGURE 2. Mormodes salazarii. A. Flowering plant; the inflorescence is actually not erect but ascending as shown in Fig. 1D; both flowers showing the ventral (stigmatic) surface of column. B, C. The same two flowers shown from the opposite side, i.e., with the dorsal surface of column (blocked from view by right-side petal). D. Detail of two pseudobulbs. E. Fruiting plant; pseudobulb viewed from the side. A-D based on Blanco 4749 (USJ), F based on Jiménez et al. 2263 (USJ). 
Distribution and habitat:-Endemic to Costa Rica. Mormodes salazarii has been collected in Calera de San Ramón (Alajuela province), the Reserva Biológica San Luis (Monteverde region, Puntarenas province) and in the Diriá National Park (Nicoya Peninsula, Guanacaste province), at recorded elevations of 660-800 m in premontane seasonal forests (possibly lower in the Nicoya Peninsula; Fig. 3).

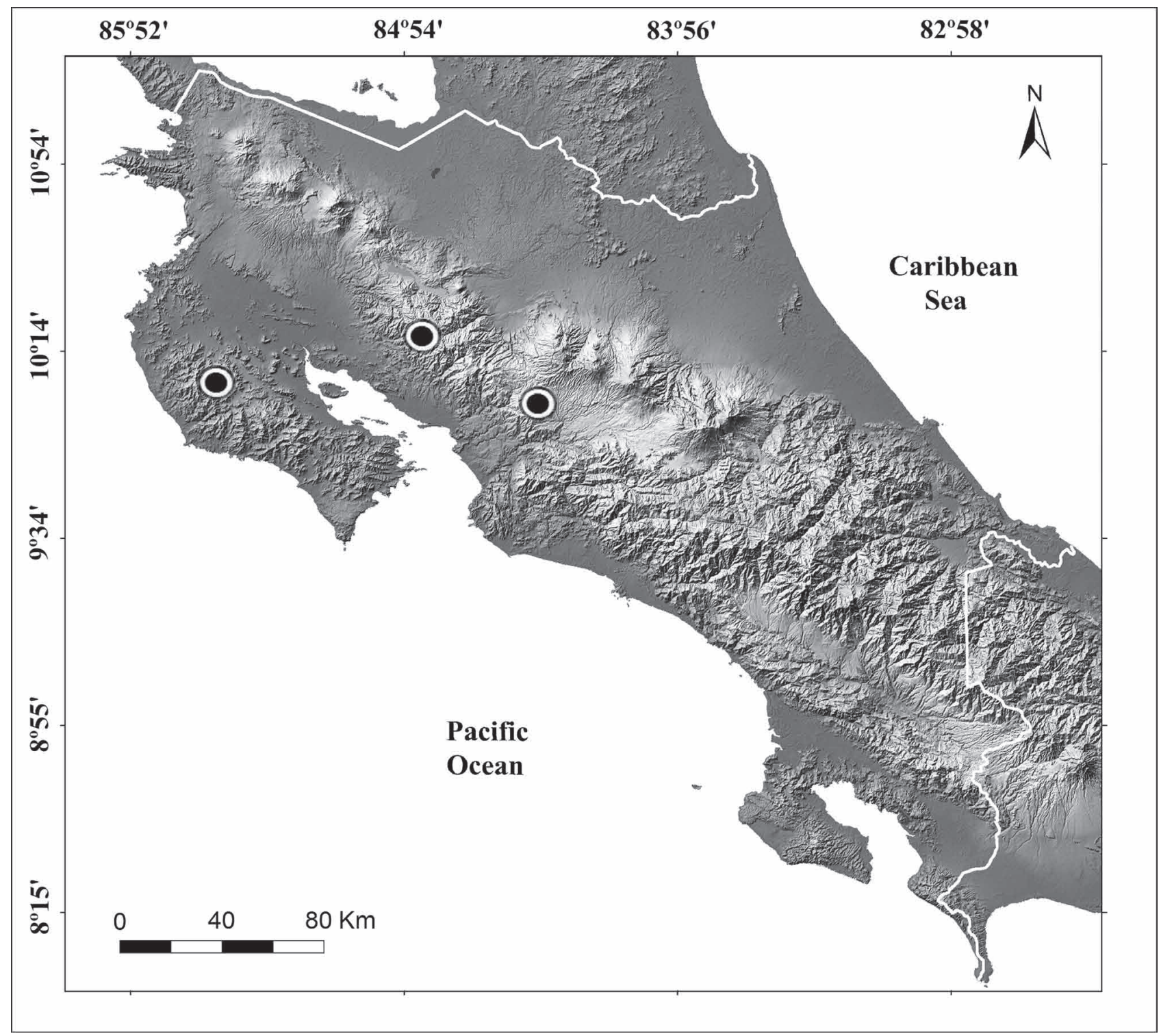

FIGURE 3. Distribution of Mormodes salazarii in Costa Rica, based on the localities of known herbarium specimens. See text for details.

One herbarium specimen of Mormodes salazarii (Morales 782, USJ; cited below) was prepared from a flowering plant bought from a street plant vendor, who said the plant was collected in Sarapiquí (Heredia province, in the Caribbean lowlands of northern Costa Rica). This locality is likely false, as all other known specimens with field data were collected in the Pacific versant of northwestern Costa Rica. Illegal orchid vendors, when asked about the origin of their plants, often provide false localities in order to mislead potential competitors. Thus, this specimen is excluded from the distribution map in Fig. 3.

We observed plants of Mormodes salazarii growing near the canyon of the Guacimal River of the San Luis Biological Reserve, mainly on rotten wood of Lysiloma divaricatum (Jacquin 1798: 76-77, pl. 395) Macbride (1919: 6) (Fabaceae), Lonchocarpus haberi Sousa (2005: 119-121, f. 1) (Fabaceae), Lonchocarpus salvadorensis Pittier (1917: 80-81, f. 31), Cedrela salvadorensis Standley (1929: 215-216) (Meliaceae), Pachira quinata (Jacquin 1760: 26) Alverson (1994: 7) (Malvaceae) and Enterolobium cyclocarpum (Jacquin 1801: 30, pl. 34, f. 1) Grisebach (1864: 226) (Fabaceae) trees. A few individuals were observed in the same locality growing in living trees of some of the species listed above.

Phenology:- -Flowering has been recorded from January to March, during the Costa Rican dry season. The fruiting plant was recorded in March. 
Additional specimens examined:-COSTA RICA. Without additional locality data: 14 February 1965 (fl.), Rodríguez 1001 (USJ). Alajuela: San Ramón, vicinity of San Ramón, Calera de San Ramón [800 m, 959`N 84³0’W fide Gazetteer of Costa Rican Plant-Collecting Locales, http://www.mobot.org/MOBOT/Research/costaricagaz. shtml], 21 January 1928 (fl.), Brenes 21030 (NY, image!). Guanacaste: Nicoya, Parque Nacional Diriá, field-collected without flowers on September 2011, flowered in cultivation on February 2012 (fl.), Deveautour s.n. (USJ). Heredia: Sarapiquí, "comprada a un vendedor de plantas en la feria del agricultor de Desamparados, quien expuso la localidad antes mencionada, <500 m", 15 January 1994 (fl.), Morales 782 (USJ; likely a false location; see comments above). Puntarenas: cantón Puntarenas, distrito Monteverde, Reserva Biológica San Luis, 664 m, 10¹5'43” N, 8449’41” W (WGS84), 29 March 2014 (fr.), Jiménez et al. 2263, (USJ).

Etymology:-Named after Gerardo A. Salazar, Ph.D., researcher at the Instituto de Biología of the Universidad Nacional Autónoma de México (UNAM) and the Mexican National Herbarium (MEXU), who has published extensively on the genus Mormodes. Dr. Salazar was the first to recognize the few early herbarium collections of this entity as a species new to science; he annotated them with the provisional name "Mormodes nicoyensis" or "M. nicoyanus", and treated the species as "Mormodes sp. B" in the most recent synopsis of the genus for Costa Rica (Salazar \& Dressler 2003). We opt to not use either of those epithets because this species is not restricted to the Nicoya Peninsula, and to honor Dr. Salazar for his many contributions to the systematics of Mormodes and the Orchidaceae in general.

Conservation status:-Mormodes salazarii is protected in Diriá National Park and in the San Luis Biological Reserve. The few specimens in herbaria and the only three known populations suggest that this species should be categorized as rare.

Herbarium collections of Mormodes and other large-flowered orchids with thick pseudobulbs are relatively few, and their paucity may not necessarily reflect their abundance. Many generalist herbarium collectors apparently refrain to collect these plants because of the perceived damage that they would provoke to the populations. On the other hand, these plants are heavily collected by unscrupulous plant vendors for the illegal plant trade, even when it is not easy to keep them alive for several years without frequent repotting and special care (Salazar et al. 2009).

Comments:-Mormodes salazarii is similar to M. fractiflexa, but differs in the non-pendulous (vs. pendulous) flowers with strongly reflexed (vs. extended to slightly reflexed) lateral sepals. Also, the flowers of M. salazarii have a white to yellowish labellum, pale cream to greenish-creamy sepals and petals and the lateral sepals without colored lines; whereas M. fractiflexa has petals and sepals (including the labellum) with the same orange-cream or yellowishcreamy color and the lateral sepals with red blurred lines.

Among Costa Rican species of Mormodes, M. salazarii is unique in the color combination of its flowers (white with pale green sepals and lateral petals). Only some plants of $M$. horichii Fowlie (1964: 6-7) have similarly greenish-white flowers (although most plants have purple flowers; Salazar \& Dressler 2003). However, that species has an apically concave labellum and occurs only on the Caribbean lowlands, on the opposite side of the continental divide. Mormodes salazarii belongs to section Mormodes, the largest and most widespread section of the genus with approximately 70 species.

\section{Acknowledgements}

We thank the Centro Científico Tropical (CCT), the non-governmental organization that owns the Reserva Biologica San Luis, for permission to collect plants in their property and for logistical and financial support to José Esteban Jiménez and Pedro Juárez. Melania Fernández, Melissa Díaz and Lizbeth Oses (Jardín Botánico Lankester, JBL) made useful suggestions to an early version of this manuscript. Gerardo Salazar (MEXU) and an anonymous reviewer provided critical additional comments and corrections.

\section{References}

Allen, P.H. (1959) Mormodes lineatum: a species in transition. American Orchid Society Bulletin 28: 411-414.

Alverson, W.S. (1994) New species and combinations of Catostemma and Pachira (Bombacaceae) from the Venezuelan Guayana. Novon 4: 3-8.

http://dx.doi.org/10.2307/3391688 
Barbosa Rodrigues, J. (1877) Genera et species orchidearum novarum. I. Imprimerie de C. \& H. Fleiuss, Sebastianopolis, $295+\mathrm{xvi} \mathrm{pp} \mathrm{+}$ additional unnumbered pages with text and illustrations. Available from: http://www.botanicus.org/page/407736 (accessed 14 June 2015)

Batista, J.A.N., Mota, A.C.M., Proite, K., de bem Bianchetti, L., Romero-González, G.A., Espinoza, H.M. \& Salazar, G.A. (2014) Molecular phylogenetics of Neotropical Cyanaeorchis (Cymbidieae, Epidendroideae, Orchidaceae): geographical rather than morphological similarities plus a new species. Phytotaxa 156 (5): 251-272.

http://dx.doi.org/10.11646/phytotaxa.156.5.1

Brown, R. (1813) Cyrtopodium andersonii, ed. 2. Hortus Kewensis 5: 216. Available from: http://gallica.bnf.fr/ark:/12148/bpt6k96729x/ f219.image (accessed 14 June 2015)

Chase, M.W. \& Hills, H.G. (1992) Orchid phylogeny, flower sexuality, and fragrance seeking. BioScience 42: 43-49. http://dx.doi.org/10.2307/1311627

Chase, M.W., Cameron K.M., Barrett R.L. \& Freudenstein J.V. (2003) DNA data and Orchidaceae systematics: a new phylogenetic classification. In: Dixon, K.W., Kell, S.P., Barrett, R.L. \& Cribb, P.J. (Eds.) Orchid Conservation. Natural History Publications, Kota Kinabalu, Sabah, pp. 69-89.

Chase, M.W., Cameron K.M., Freudenstein J.V., Pridgeon A.M., Salazar G., van den Berg C. \& Schuiteman A. (2015) An updated classification of the Orchidaceae. Botanical Journal of the Linnean Society 177: 151-174.

http://dx.doi.org/10.1111/boj.12234

Dodson, C.H. (1962) Pollination and variation in the subtribe Catasetinae (Orchidaceae). Annals of the Missouri Botanical Garden 49: $35-56$.

http://dx.doi.org/10.2307/2394740

Dodson, C.H. (1975) Dressleria and Clowesia: a new genus and an old one revived in the Catasetinae (Orchidaceae). Selbyana 1: 130137. Available from: http://www.jstor.org/stable/41759589 (accessed 16 August 2015)

Dressler, R.L. (1968) Observations on orchids and euglossine bees in Panama and Costa Rica. Revista de Biología Tropical 15: $143-183$. Available from: http://www.ots.ac.cr/rbt/attachments/volumes/vol15-1/07-Dressler-Orchids.pdf (accessed 27 December 2015)

Dressler, R.L. (1981) The orchids. Natural history and classification. Harvard University, Cambridge, 332 pp.

Dressler, R.L. (1993) Field guide to the orchids of Costa Rica and Panama. Comstock Publishing Associates, Ithaca, 374 pp.

Fowlie, J.A. (1964) Search for orchids - A new Mormodes from the Sarapiqui District of Costa Rica. Lasca Leaves 14: 4-7. Available from: http://www.biodiversitylibrary.org/item/130954\#page/343/mode/1up (accessed 25 August 2015)

Freudenstein, J.V. \& Chase, M.W. (2015) Phylogenetic relationships in Epidendroideae (Orchidaceae), one of the great flowering plant radiations: progressive specialization and diversification. Annals of Botany 115: 665-681. http://dx.doi.org/10.1093/aob/mcu253

Grisebach, A.H.R. (1864) Flora of the British West Indian Islands. Lovell, Reeve \& Co., London, 789 pp. http://dx.doi.org/10.5962/bhl.title.106964

Horich, C.K. (1976) The enigmatic Mormodes of Costa Rica. Orchid Digest 40: 219-222.

Jacquin, N.J. (1760) Enumeratio Systematica Plantarum, quas in insulis Caribaeis vicinaque Americes continente detexit novas, aut jam cognitas emendavit. Theodorum Haak, Lugduni Batavorum, 41 pp.

http://dx.doi.org/10.5962/bhl.title.100687

Jacquin, N.J. (1798) Plantarum rariorum horti caesarei schonbrunnensis, volume 3. C.F. Wappler, Vienna, 80 pp. + T. 251-400. Available from: http://www.botanicus.org/page/272467 (accessed 16 August 2015)

Jacquin, N.J. (1801) Fragmenta Botanica. Mathiae Andreae Schmidt, Vienna, 86 pp. + 138 T. Available from: http://www.botanicus.org/ page/287571 (accessed 16 August 2015)

Jiménez, J.E., Juárez P. \& Díaz A. (In press) Checklist of the vascular flora of Reserva Biológica San Luis, Costa Rica. CheckList.

Kunth, K.S. (1822) Synopsis plantarum, quas, in itinere ad plagam aequinoctialem orbis novi, collegerunt Al. De Humboldt et Am. Bonpland 1. F.G. Levrault, Paris, 491 pp. Available from: https://archive.org/details/synopsisplantar02bonpgoog (accessed 14 June 2015)

Lindley, J. (1830) Illustrations of orchidaceous plants. James Ridgway \& Sons, London, xvi pp + 15 Tabs. + 20 Tabs. Available from: https://books.google.com/books?id=ww9JAAAAcAAJ\& (accessed 16 August 2015)

Lindley, J. (1833) The genera and species of orchidaceous plants. James Ridgway \& Sons, London, 553 pp. Available from: http://www. biodiversitylibrary.org/page/393415 (accessed 27 April 2015)

Lindley, J. (1835) Grobya amherstiae. Lady Amherst's Grobya. Edwards's Botanical Register 20: t. 1740. Available from: http://www. botanicus.org/item/31753002748322 (accessed 14 June 2014)

Lindley, J. (1836) A Natural System of Botany. Second edition. Longman, Rees, Orme, Brown, Green \& Longman, London, 526 pp. Available from: https://archive.org/details/anaturalsystemb00lindgoog (accessed 16 August 2015)

Lindley, J. (1843a) Cycnoches pentadactilon. Five-fingered Swan neck. Edwards's Botanical Register 29: t. 22. Available from: http:// 
www.biodiversitylibrary.org/page/242284\#page/1/mode/1up (accessed 27 April 2015)

Lindley, J. (1843b) Miscellaneous matter. Edwards's Botanical Register 29: misc. 1-85. Available from: http://www.biodiversitylibrary. org/page/242284\#page/1/mode/1up (accessed 27 April 2015)

Macbride, J.F. (1919) Notes on certain Leguminosae. Contributions from the Gray Herbarium of Harvard University 59: 1-27. Available from: http://www.biodiversitylibrary.org/item/123407\#page/704/mode/1up (accessed 16 August 2015)

Monnier, G. (1992) Sexual polymorphism in the genus Mormodes. Florida Orchidist 34 (4): 180-184.

Pabst, G.F.J. (1968) El género Mormodes Lindl. en Colombia. Orquideología 3: 131-146.

Pabst, G.F.J. (1978) An illustrated key to the species of the genus Mormodes Lindl. Selbyana 2: 149-155. Available from: http://www.jstor. org/stable/41759457?seq=1\#page_scan_tab_contents (accessed 16 August 2015)

Pabst, G.F.J. (1982) Clave ilustrada de las especies del género Mormodes Lindl. Orquideología 15: 171-189.

Pérez-Escobar, O.A., Balbuena, J.A. \& Gottschling, M. (2016) Rumbling orchids: How to assess divergent evolution between chloroplast endosymbionts and the nuclear host. Systematic Biology 65: 51-65.

http://dx.doi.org/10.1093/sysbio/syv070

Pfitzer, E. (1888-1889) Orchidaceae. In: Engler, A. \& Prantl, K. (Eds.) Die natürlichen Pflanzenfamilien II, teil 6. Wilhelm Engelmann, Leipzig, pp. 52-224. Available from: http://www.biodiversitylibrary.org/item/56456\#page/880/mode/1up (accessed 15 June 2015)

Pijl, L. van der \& Dodson, C.H. (1966) Orchid flowers - their pollination and evolution. Fairchild Tropical Gardens and The University of Miami, Coral Gables, 214 pp.

Pittier, H.F. (1917) The middle American species of Lonchocarpus. Contributions from the United States National Herbarium $20: 37-93$. Available from: http://biodiversitylibrary.org/item/13780\#page/51/mode/1up (accessed 16 August 2015)

Pridgeon A.M. \& Chase M.W. (1998) Phylogenetics of subtribe Catasetinae (Orchidaceae) from nuclear and chloroplast DNA sequences. In: Pereira, C.E.B. (Ed.) Proceedings of the $15^{\text {th }}$ World Orchid Conference. Naturalia, Turriers, pp. 275-281.

Reichenbach, H.G. (1872) New garden plants. The Gardeners' Chronicle and Agricultural Gazette 5: 141. Available from: http://www. biodiversitylibrary.org/page/26128753\#page/159/mode/1up (accessed 27 April 2015)

Romero, G.A. (1990) Phylogenetics relationships in subtribe Catasetinae (Orchidaceae, Cymbidieae). Lindleyana 5: 160-181.

Romero, G.A. \& Pridgeon, A.M. (2009) Subtribe Catasetinae. In: Pridgeon, A.M., Cribb, P.J., Chase, M.W. \& Rasmussen, F.N. (Eds.) Genera Orchidacearum Volume 5: Epidendroideae (Part Two). Oxford University, Oxford, pp. 11-12.

Salazar, G.A. (1991) Quelques observations sur le genre Mormodes. Orchidophile 98: 167-172.

Salazar, G.A. (1994a) A review of the Buccinator-like Mormodes (Orchidaceae) of Mexico. Orchid Digest 58: 38-44.

Salazar, G.A. (1994b) Recent advances and problems in taxonomy of Mormodes. In: Pridgeon, A.M. (Ed.) Proceedings of the $14^{\text {th }}$ World Orchid Conference. Her Majesty's Stationary Office, Glasgow, pp. 100-104.

Salazar, G.A. (1999) Sistemática de Mormodes sección Coryodes (Orchidaceae, Catasetinae). Master's thesis, Universidad Nacional Autónoma de México, México D.F., 161 pp. Available from: http://132.248.9.195/pd1999/269965/Index.html (accessed 15 June 2015)

Salazar, G.A. \& Romero, G.A. (1994) Novelties in Mormodes (Orchidaceae) from the Venezuelan Guyana. Lindleyana 9: 255-263.

Salazar, G.A. \& Dressler, R.L. (2003) Mormodes. In: Hammel, B.E., Grayum, M.H., Herrera, C. \& Zamora, N. (Eds.) Manual de plantas de Costa Rica, volumen III: Monocotiledóneas (Orchidaceae-Zingiberaceae). Systematic Botany Monographs from the Missouri Botanical Garden 93: 335-338. Available from: http://www.botanicus.org/item/31753003149553 (accessed 15 June 2015)

Salazar, G.A., Romero-González, G.A., Veitch, N.C. \& Grayer, R.J. (2009) Mormodes. In: Pridgeon, A.M., Cribb, P.J., Chase, M.W. \& Rasmussen, F.N. (Eds.) Genera Orchidacearum Volume 5: Epidendroideae (Part Two). Oxford University, Oxford, pp. 35-40.

Sousa, M. (2005) Especies nuevas de Lonchocarpus (Millettieae: Leguminosae) para Costa Rica y Panamá: lecotipificación de la sect. Densiflori Benth. Revista Mexicana de Biodiversidad 76: 119-127. Available from: http://www.scielo.org.mx/scielo.php?script=sci_ arttext\&pid=S1870-34532005000200001\&lng=es\&nrm=iso\&tlng=es (accessed 16 August 2015)

Standley, P.C. (1929) Studies of American plants - I. Publications of the Field Museum of Natural History, Botanical Series 4: 197-299. Available from: http://www.biodiversitylibrary.org/item/19673\#page/7/mode/1up (accessed 16 August 2015)

Whitten, W.M., Neubig, K.M. \& Williams, N.H. (2014) Generic and subtribal relationships in Neotropical Cymbidieae (Orchidaceae) based on matK/ycf1 plastid data. Lankesteriana 13: 375-392. Available from: http://www.lankesteriana.org/lankesteriana/ Lankesteriana\%2013(3)/19\%20Whitten\%20at\%20al.pdf (accessed 15 June 2015) 